\title{
A Description of Some Lignanolytic Soil Bacteria and their Ability to Oxidize Simple Phenolic Compounds
}

\author{
BY VERONICA SUNDMAN \\ Department of Microbiology, University of Helsinki, Pihlajamäki Finland
}

(Received 11 September 1963)

\begin{abstract}
SUMMARY
Bacteria able to decompose $\alpha$-conidendrin were isolated from three of five soil samples by enrichment on this compound as sole source of carbon and energy. All the isolates obtained were small Gram-negative motile poorly flagellated rods, which were classified as members of the genus Agrobacterium. The ability of these bacteria to oxidize phenolic compounds was examined by manometric studies. From calculations of oxygen uptake, it was concluded that the oxidative rupture of the benzene ring of $m$ - and $p$-hydroxybenzoic acid by these bacteria could not be explained entirely by the known metabolic paths which lead from these hydroxybenzoic acids to protocatechuic acid or gentisic acid. It was indicated by simultaneous adaptation technique that neither monohydroxybenzoic acids nor monohydroxycinnamic acids were likely to be formed during the oxidative breakdown of $\alpha$-conidendrin by these agrobacteria.
\end{abstract}

\section{INTRODUCTION}

In the first paper of this series (Sundman, 1962) a new type of $\alpha$-conidendrin degradation by bacteria was described. It was shown that in contrast to earlier reported bacterial attacks on $\alpha$-conidendrin and other methoxylated aromatic compounds (Konetzka, Woodings \& Stove, 1957; Tabak, Chambers \& Kabler, 1959), which were interpreted to proceed via vanillic acid as an intermediate, the present bacteria produce no vanillic acid but considerable amounts of isovanillic acid during the breakdown of $\alpha$-conidendrin. The decomposition was assumed to occur according to Fig. 1, with the 6- $\alpha$-bound guaiacyl group $\mathrm{A}$ being conserved in the isovanillic acid, which was believed to be further oxidized, possibly via $m$-hydroxybenzoic acid, to protocatechuic acid. In previous work (Konetzka et al. 1957; Tabak et al. 1959) $p$-hydroxybenzoic acid was reported as intermediate in the bacterial degradation of $\alpha$-conidendrin via vanillic acid, and in the oxidation of trimethoxybenzoic acid by a soil bacterium (Konetzka et al. 1957). p-Hydroxycinnamaldehyde arises during decomposition of spruce native lignin by various white-rot fungi (Ishikawa, Schubert \& Nord, $1963 a, b$ ). It is not known which metabolic sequences could replace a methoxyl group by a hydrogen atom under aerobic conditions thus forming, e.g. $p$-hydroxybenzoic acid from vanillic acid or $m$-hydroxybenzoic acid from isovanillic acid. The position of the mono-substituted benzoic and cinnamic acids in the oxidative breakdown of guaiacyl compounds remains obscure. To acquire more information about the mode of action of the bacteria, this work was enlarged to include the hydroxybenzoic acids and 
hydroxycinnamic acids in addition to diphenolic acids and pyrocatechol, which are known as key intermediates in the oxidative breakdown of the aromatic structure (Rogoff, 1961). Further, the oxidation of phenol, benzoic acid and cinnamic acid was investigated. By the simultaneous adaptation technique (Stanier, 1947) organisms<smiles>O=C(O)C=Cc1ccccc1</smiles>

Cinnamic acid<smiles>O=C(O)c1ccccc1</smiles>

Benzoic acid<smiles>COc1cc(C(=O)O)ccc1O</smiles>

Vanillic acid<smiles>COc1ccc(C(=O)O)cc1O</smiles>

isoVanillic acid

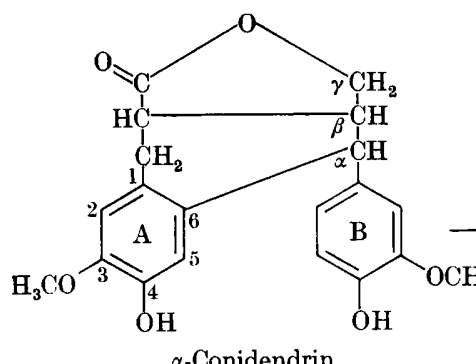

$\alpha$-Conidendrin<smiles>COc1ccc([14CH](C)C)c(O)c1</smiles>

isoVanillic acid<smiles>O=C(O)c1cccc(O)c1</smiles>

$m$-Hydroxybenzoic acid<smiles>O=C(O)c1ccc(O)c(O)c1</smiles>

Protocatechuic acid

Supposed mode of formation of $i$ sovanillic acid from $\alpha$-conidendrin by the bacteria under investigation (Sundman, 1962).

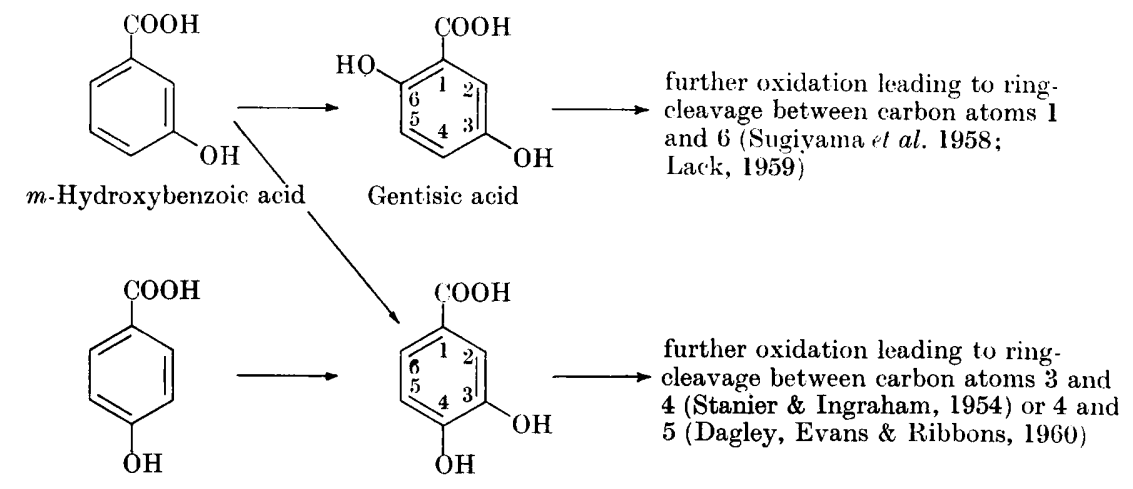

$p$-Hydroxybenzoic acid Protocatechuic acid

Metabolic paths of $m$-hydroxybenzoic acid and $p$-hydroxybenzoic acid by bacteria.

Fig. 1. Chemical structures of individual compounds and pathways.

of both $\alpha$-conidendrin-adapted and non-adapted cultures were examined, and an attempt made to determine whether some of these substances were intermediates in the degradation of $\alpha$-conidendrin.

The $\alpha$-conidendrin-decomposing bacteria previously described belong to the genera Pseudomonas (Tabak et al. 1959) and Flavobacterium (Konetzka, Pelczar \& Gottlieb, 1952). These genera seem to demand special attention in any attempt to 
clarify the ligninolytic microflora of the soil. It has been shown that pseudomonads and flavobacteria originating in soil decompose Braun's native lignin, and proliferate on this material as sole source of energy (Sörensen, 1962) and further, that Pseudomonas fluorescens strains are capable of oxidizing a number of lignin preparations (Higuchi, Kavamura \& Hayashi, 1956). The conidendrin-decomposing bacteria isolated by the author (Sundman, 1962) showed some resemblance to certain pseudomonads but also features of the genus Agrobacterium. The present paper examines the results of attempts to determine the taxonomic position of the lignanolytic bacteria which produce isovanillic acid.

\section{METHODS}

Soil samples. Five samples, rich in wood residue, were selected. $\alpha$-Conidendrindecomposing bacteria were isolated from soil sample $\mathrm{Ks}$, decaying sawdust (Helsinki), pH 5.5; soil sample Ms, forest soil (Helsinki), under Oxalis and Myrtillus; soil sample $\mathrm{O}$, decaying pile of brush wood (Teisko), pH 5.5. None was obtained from two other samples of forest soil, and a decaying stub, respectively.

Isolation of the bacteria. As previously described (Sundman, 1962), the $\alpha$-conidendrin-decomposing bacteria were isolated from soil samples by enrichment through several subcultures in a nitrate + mineral salts + vitamin basal medium to which $0.5 \%(\mathrm{w} / \mathrm{v})$ of $\alpha$-conidendrin crystals were added as the carbon +energy source. The base solution (K-solution) contained: $\mathrm{NaNO}_{3}, 2.5 \mathrm{~g}$.; $\mathrm{KH}_{2} \mathrm{PO}_{4}, \mathbf{1} \cdot 0 \mathrm{~g}$.; $\mathrm{CaCl}_{2}, 0 \cdot 1 \mathrm{~g}$.; $\mathrm{MgSO}_{4} .7 \mathrm{H}_{2} \mathrm{O}, 0.3 \mathrm{~g}$.; $\mathrm{NaCl}, 0 \cdot 1 \mathrm{~g}$.; $\mathrm{FeCl}_{3}, 0.01 \mathrm{~g}$.; vitamin solution (thiamine $10 \mathrm{mg}$., Ca-panthothenate $10 \mathrm{mg}$, biotin $20 \mu \mathrm{g}$, $\mathrm{B}_{12}$ vitamin $40 \mu \mathrm{g}$., pyridoxin $10 \mathrm{mg}$., nicotinic acid $10 \mathrm{mg}$., $p$-aminobenzoic acid $10 \mathrm{mg}$., folic acid $2 \mathrm{mg}$., dissolved in $200 \mathrm{ml}$. of water) $5 \mathrm{ml}$; ; water $1000 \mathrm{ml}$. final $\mathrm{pH} \mathrm{6.5}$. For isolation, the enrichment cultures were plated on KYE agar (K-solution + Bacto yeast extract $0 \cdot 1 \%(\mathrm{w} / \mathrm{v})+$ agar $2 \%(\mathrm{w} / \mathrm{v})$. The isolates were replated on the same medium, and the ability to decompose $\alpha$-conidendrin was noted as a darkening upon growth in the liquid enrichment medium with $\alpha$-conidendrin as sole source of carbon + energy. About $10 \alpha$-conidendrin-decomposing isolates from each soil sample were kept as stock cultures for further work, with monthly transfers on: (a) semi-solid KYE agar (KYE agar with agar content decreased to $0.3 \% \mathrm{w} / \mathrm{v}) ;(b)$ the liquid $\alpha$-conidendrin-containing medium.

Manometry. The respirometric experiments were made with washed organisms. These were grown at $28^{\circ}$ for 2 days in Roux bottles on KYE agar + glucose $0 \cdot 2 \%$ $(\mathrm{w} / \mathrm{v})+$ yeast extract $0 \cdot 1 \%(\mathrm{w} / \mathrm{v})$. (Organisms Ms 144412 were difficult to handle when grown on glucose-containing medium because of heavy slime production. Glucose was therefore omitted from the medium for growing this bacterium.) For the production of $\alpha$-conidendrin-adapted bacteria, $\alpha$-conidendrin $0.05 \%(w / v)$ was added to the medium. The bacteria were harvested by the aid of glass beads and water, and the suspension filtered through glass wool to remove large agar particles. The centrifuged organisms were washed three times with 1/15 M-phosphate buffer pH 5.9), and re-suspended in the same buffer, about $6 \times 10^{10}$ viable organisms $/ \mathrm{ml}$. according to plate counts. The Warburg vessels were filled with: $0.5 \mathrm{ml}$. suspension of organisms; $1.0 \mathrm{ml}$. of substrate (1-2.8 $\mu$ mole in water, $\mathrm{pH} \mathrm{7.0);0.2} \mathrm{ml.} 20 \%(\mathrm{w} / \mathrm{v})$ potassium hydroxide in the centre well. The technique recommended by Umbreit, 
Burris \& Stauffer (1957) was used. In determining the total oxygen consumption, the substrate was added to the main compartment and the bacteria tipped from the side arm to avoid error caused by droplets adhering to the walls of side arm after tipping. The results given are means of duplicate manometer readings.

Growth experiments. To determine whether a compound served as carbon + energy source for the bacteria, washed organisms were inoculated as stab cultures into semisolid $\mathrm{K}$ agar (K-solution $+\mathbf{0 . 3} \%, \mathrm{w} / \mathrm{v}$, Bacto agar), and into similar media with 0.001 and $0.0001 \mathrm{~mole} / \mathrm{ml}$., respectively, of compound to be tested. Since these bacteria are not able to utilize agar, the control inoculation into semi-solid $\mathbf{K}$ agar served as a check on possible carbon + energy sources transferred with the inoculum or present in the medium. The growth in the tubes provided with compound to be tested is quoted as positive only when the control tube showed no growth.

Phenolic compounds used. $\alpha$-Conidendrin was kindly supplied by the Crown \& Zellerbach Corporation (Camas, Washington state, U.S.A.). The white crystals were dissolved in acetone and re-precipitated from water, m.p. 247-248 ${ }^{\circ}$. Other compounds were commercially available preparations as follows : $o$-hydroxybenzoic acid (British Drug Houses Ltd, reagent) m.p. $157-158^{\circ} ; m$-hydroxybenzoic acid (puriss.) m.p. 198-199 ${ }^{\circ} ; p$-hydroxybenzoic acid (purum) m.p. 212-214 ${ }^{\circ} ; o$-hydroxycinnamic acid (purum) m.p. 207-209 ${ }^{\circ}$; $m$-hydroxycinnamic acid (purum) m.p. 192-193 ${ }^{\circ}$; $p$-hydroxycinnamic acid (puriss.) m.p. 214-215 ${ }^{\circ}$; protocatechuic acid (purum) m.p. 200-201 ${ }^{\circ}$; gentisic acid (puriss.) m.p. 202-204 ${ }^{\circ}$; homogentisic acid (purum) m.p.147-149 ${ }^{\circ}$, all from Fluka A.G. (Buchs, S.G., Switzerland); pyrocatechol (p.a.) m.p. 104-105 ${ }^{\circ}$; phenol (p.a. for chromatography) m.p. 39-39.5 ${ }^{\circ}$, both from Merck Co., Inc. (Darmstadt, Western Germany).

\section{RESULTS}

\section{Identification and taxonomy of the $\alpha$-conidendrin-decomposing bacteria}

All the $\alpha$-conidendrin-decomposing isolates obtained from the three soil samples were motile, non-sporing, Gram-negative single rods, $0 \cdot 9-1$ by $1 \cdot 3-3 \cdot 2 \mu$, with a tendency to uneven staining and Gram variability. No pigment was produced on ordinary media. The isolates from each soil sample showed only minor differences in physiological tests, and were obviously representatives of the same species. One isolate for each soil sample was selected for further study, and replated twice to ensure purity. Of these isolates: $\mathrm{Ks} 17, \mathrm{O}$, Ms 14, the two first named were used in previous work (Sundman, 1962). The isolates had since been kept as stock cultures for a year. They showed no sign of impurity, but for the identification purposes of the present work their purity was ascertained by repeated platings. Though visually homogeneous, the plates were not considered as proofs of purity until all the colonies from a plate gave visually identical cultures in stabs in semi-solid KYE agar, were positive in the test for $\alpha$-conidendrin degradation, and showed the same morphology under the phase-contrast microscope. This was achieved after two platings of isolates $\mathrm{Ks} 17$ and $\mathrm{O} \mathrm{8}$, and four platings of isolate Ms 14. The replated cultures are designated Ks 1741, $\mathrm{O}$ 811, and Ms 144412.

Each isolate was aerobic, growing as sharply confined surface upon stabbing in semi-solid KYE agar; growth was good at $15^{\circ}$ and $28^{\circ}$, the minimum temperature for growth was less than $3^{\circ}$, and the maximum below $37^{\circ}$. Tests for hydrolysis of 
gelatin, casein and starch (on KYE agar plates containing $0.4 \%$, w/v, gelatine, $20 \%$, w/v, skimmed milk, and $0 \cdot 2 \%, w / v$, soluble starch, respectively) were negative. Indole was not produced in the $1 \%(\mathrm{w} / \mathrm{v})$ tryptone solution, nor hydrogen sulphide in the mannitol tryptone medium of ZoBell \& Feltham (1934). In the Hugh \& Leifson (1953) test for the type of carbohydrate metabolism, no acid or gas from glucose was detected during the 10 days of incubation; when incubation was extended to 21 days, the open tube turned yellow. Substances tested as sole carbon + energy sources supporting growth were: glucose, galactose, mannose, xylose,

Table 1. Characteristics which varied in the $\alpha$-conidendrin-decomposing isolates $\mathrm{Ks} 1741, \mathrm{Ms} 144412$ and $\mathrm{O} 811$

\begin{tabular}{|c|c|c|c|}
\hline \multirow[b]{2}{*}{ Determinative test } & \multicolumn{3}{|c|}{ Isolate } \\
\hline & Ks 1741 & Ms 144412 & O 811 \\
\hline Flagella staining & $\begin{array}{l}\text { 1-2 polar (and/or } \\
\text { lateral) }\end{array}$ & 1-5 peritrichous & $\begin{array}{l}\text { 1-3 polar (and/or } \\
\text { subpolar) }\end{array}$ \\
\hline $\begin{array}{l}\text { Oxidase test (dimethyl-p- } \\
\text { phenylene diamine } \mathrm{HCl} \text { solu- } \\
\text { tion poured on KYE agar } \\
\text { surface growth }\end{array}$ & + & - & + \\
\hline $\begin{array}{l}\text { Nitrite from nitrate (in KYE } \\
\text { medium) }\end{array}$ & $+^{*}$ & - & $+^{*}$ \\
\hline $\begin{array}{l}\text { Litmus milk (21 days, } 28^{\circ} \text { ), } \\
\text { Hofer (1941) }\end{array}$ & $\begin{array}{l}\text { Slight alkalization, } \\
\text { reduction at the } \\
\text { bottom. No } \\
\text { browning }\end{array}$ & $\begin{array}{l}\text { Slimy serum zone } \\
\text { at the surface. } \\
\text { Milk yellowish } \\
\text { brown }\end{array}$ & $\begin{array}{l}\text { Slight alkalization, } \\
\text { reduction at the } \\
\text { bottom. No } \\
\text { browning }\end{array}$ \\
\hline $\begin{array}{l}\text { Growth on Caglycerophosphate- } \\
\text { mannitol agar (Riker et al. } \\
\text { 1930) }\end{array}$ & $\begin{array}{l}\text { Brown pigment, } \\
\text { surrounded by } \\
\text { white precipitate }\end{array}$ & $\begin{array}{l}\text { No colour, abun- } \\
\text { dant white preci- } \\
\text { pitate }\end{array}$ & $\begin{array}{l}\text { Brown pigment, } \\
\text { surrounded by } \\
\text { white precipitate }\end{array}$ \\
\hline Absorption of Congo red & \pm & + & - \\
\hline Assimilation of arabinose & - & + & - \\
\hline
\end{tabular}

* Nitrates completely assimilated, test for nitrite negative upon growth in medium containing glycerol + nitrate $(0 \cdot 025 \%, \mathrm{w} / \mathrm{v})$

mannitol, glycerol, citric acid, gluconic acid, protocatechuic acid, hydroxybenzoic acids, hydroxycinnamic acids (see Table 2). Lactose, saccharose, vanillic acid, vanillin, cinnamic acid, ferulic acid, guaiacol, eugenol, isoeugenol, and phenol did not serve as carbon + energy source. All the isolates were negative in the test for alkaline arginine metabolism (Thornley, 1960), did not produce alkalinity when grown in a medium containing potassium nitrate+glycerol (Sagen, Riker \& Baldwin, 1934), and were resistant to $100 \mathrm{i} . \mathrm{u}$. penicillin/ml. KYE agar.

Table 1 illustrates the behaviour of isolates Ks 1741, O 811, and Ms 144412 in some additional tests, in which variable results were obtained. The flagellation of these bacteria, as reported in Table 1, represents the conclusions from numerous tests by Leifson's method, with tannic acid + ethanolic fuchsin (Leifson, 1960), and Fontana's method with silver nitrate as described by Rhodes (1958). Some unknown feature of these organisms made clear-cut flagella-stained preparations difficult to obtain by reason of heavy precipitation of stain around the organisms. In the main, isolates $\mathrm{O} 811$ and $\mathrm{Ks} \mathbf{1 7 4 1}$ had polar flagellation, but lateral and sub-polar flagella 
were noted repeatedly. To decide whether these latter were artefacts caused by overlapping of soma and flagellum (Hodgkiss, 1960) Agrobacterium tumefaciens (kindly supplied by Professor O. Pohjakallio, Department of Plant Pathology, University of Helsinki) and Pseudomonas spp. (isolated in this laboratory from market milk) were included as peritrichously flagellate and polarly flagellate test organisms, respectively, for the flagella staining techniques used. The preparations obtained with $A$. tumefaciens and $\alpha$-conidendrin-decomposers Ks 1741 and $\mathrm{O} 811$ were almost indistinguishable, showing few flagella, and in situations which were mainly polar and occasionally lateral or sub-polar. The same precipitation of stain around the organisms was noted in all the preparations. The Pseudomonas spp. cultures gave preparations with clear-cut polar flagella only, and without the disturbing precipitate around the organisms. All the isolates were thus to be considered as peritrichously flagellate, and a location in the genus Pseudomonas excluded. This is supported by the negative test for alkaline arginine metabolism obtained with the isolates. This test was useful for the differentiation of pseudomonads from other Gram-negative organisms, isolated from spoiled chicken meat, (Thornley, 1960), and according to Brisbane \& Rovira (1961) of value also in the separation of soil pseudomonads from other Gram-negative soil bacteria.

In a system for the classification of Gram-negative soil bacteria (Holding, 1960), those aerobic organisms which possess peritrichous flagella and are capable of oxidizing glucose and of growth on inorganic nitrogen are allocated to the genus Agrobacterium. According to this classification, the $\alpha$-conidendrin-decomposing bacteria described here would be considered as agrobacteria. Of the seven Agrobacterium species listed in the 7th edition of Bergey's Manual (1957), five are plant pathogens, $\boldsymbol{A}$. radiobacter is a common soil organism, and one species, $\boldsymbol{A}$. stellulatum, was isolated from marine mud. On the basis of their growth in litmus milk, and the action on carbohydrates, the present isolates examined here display most resemblance to $A$. radiobacter. Inability to produce hydrogen sulphide, colourless growth on Ca glycerophosphate-mannitol agar (Ms 144412), neutral reaction in nitrate + glycerol medium, growth in litmus milk without production of brown colour (Ks 1741, O 811), and the absorption of congo red (Ms 144412) indicate that none of the isolates listed in Table 1 can be considered as typical $A$. radiobacter. It is believed that they belong to the still rather obscure $A$. radiobacter group of the indigenous soil flora described by Conn (1942, 1948).

\section{Oxidation of aromatic key intermediates}

In manometric studies of the oxidative properties of the bacteria, it was found that a common feature of these $\alpha$-conidendrin-decomposers was a constitutive ability to oxidize protocatechuic acid (PA) and homogentisic acid (HGA) (see Figs. 2, 3). Strains Ms 144412 and 0811 oxidized pyrocatechol (PC) at a comparable rate, and strains $\mathrm{O} \mathbf{8 1 1}$ and $\mathrm{Ks} \mathbf{1 7 4 1}$ also oxidized gentisic acid (GA) at a slower rate (see Fig. 3). No induction was required for the oxidation of these substrates. Organisms grown on yeast extract + glucose started oxygen uptake immediately, with no lag. The Agrobacterium tumefaciens strain included lacked the ability to oxidize these phenolic acids. The oxidation of PA, HGA, and PC was viewed in relationship to the ability of the organisms to oxidize various aromatic compounds of lignin-like structure (Sundman, 1964). The simultaneous adaptation technique could 
not provide information on whether these aromatic key intermediates were actually intermediates in the $\alpha$-conidendrin breakdown, since under the experimental conditions the organisms contained the systems for their oxidation independently of whether $\alpha$-conidendrin was present during growth or not. Protocatechuic acid was indicated by paper chromatography (for technique see Sundman, 1962) in $\alpha$-conidendrin culture filtrates.

Strain Ms 144412, though constitutively oxidizing homogentisic acid, lacked the ability to oxidize gentisic acid (Table 2). This provided evidence that the homogentisic acid oxidation by this strain did not proceed via gentisic acid formation. This latter compound was assumed to be an intermediate in the oxidation of homogentisic acid by an enzyme preparation of a white-rot fungus (Fukuzumi, 1962).

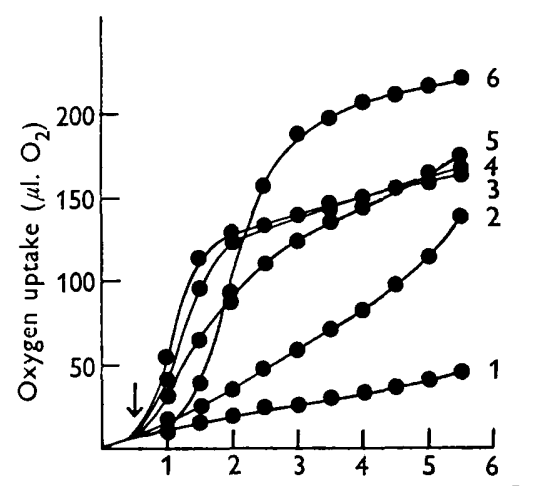

Time elapsed since start of readings (hr)

Fig. 2

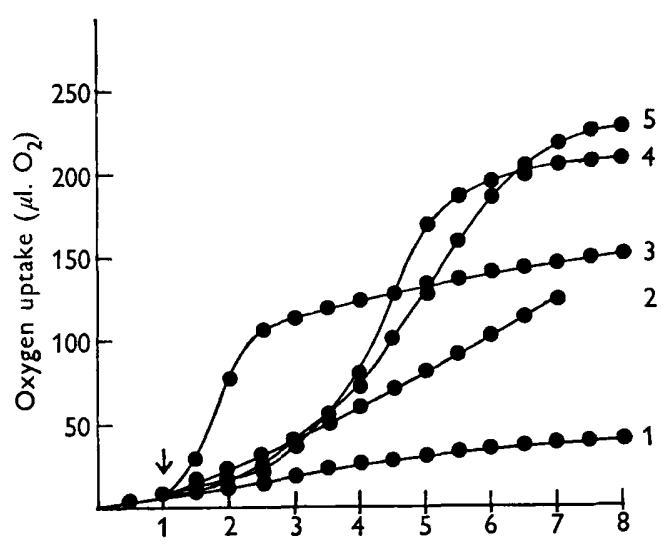

Time elapsed since start of readings (hr)

Fig. 3

Fig. 2. Oxygen uptake by $\alpha$-conidendrin-adapted organisms of strain Ks 1741 with various phenolic acids and $\alpha$-conidendrin. Number of viable organisms: $3 \cdot 88 \times 10^{10}$. Amount of substrate: phenolic acids, $2 \mu$ mole; $\alpha$-conidendrin, $1 \mu$ mole. 1 , Endogenous; 2, $m$-hydroxycinnamic acid; 3 , protocatechuic acid; 4 , homogentisic acid; 5 , $\alpha$-conidendrin; 6, $m$-hydroxybenzoic acid. $\downarrow$ addition of substrate.

Fig. 3. Oxygen uptake by organisms of stain $O 811$ (not adapted to $\alpha$-conidendrin during growth) with phenolic acids. Number of viable organisms: $3 \cdot 45 \times 10^{10}$. Amount of substrate: $2 \mu$ mole. 1, Endogenous; 2, gentisic acid; 3, protocatechuic acid; $4, p$ hydroxybenzoic acid; $5, m$-hydroxybenzoic acid. $\downarrow=$ addition of substrate.

\section{Oxidation and metabolic paths of monohydroxybenzoic acids and monohydroxycinnamic acids}

From the figures for total oxygen uptake given in Table 2, it can be seen to what extent the hydroxybenzoic acids and hydroxycinnamic acids are oxidized by the present bacteria. It was found that when the acids served as substrate, an induction time of 30-90 min. was required before oxygen uptake started (Fig. 3), $m$-hydroxycinnamic acid being an exception. This substrate was oxidized at increasing rate without a well-defined lag (Fig. 2). Adaptation to $\alpha$-conidendrin during growth could not suppress the induction time required by the agrobacteria to start oxygen uptake with the hydroxybenzoic acids and hydroxycinnamic acids as substrates. Neither was the slow initial oxygen uptake with $m$-hydroxycinnamic acid as 
substrate accelerated by presence of $\alpha$-conidendrin during growth. There was thus no evidence presented for the position of monohydroxybenzoic acids or monohydroxycinnamic acids as intermediates in the decomposition of $\alpha$-conidendrin by the present agrobacteria. None of these acids were detected by aid of previously described paper chromatographical technique (Sundman, 1962) in filtrates of $\alpha$-conidendrin cultures.

Table 2. Total oxygen uptake (mole oxygen/mole substrate) observed in respirometric experiments with $\alpha$-conidendrin-decomposing Agrobacterium strains, with washed organisms harvested from glucose +yeast extract + minerals

Organism

\begin{tabular}{|c|c|c|c|c|c|c|}
\hline \multirow[b]{2}{*}{ Substrate } & \multicolumn{2}{|c|}{ Ks 174,1} & \multicolumn{2}{|c|}{ Ms 144412} & \multicolumn{2}{|c|}{ O 811} \\
\hline & $\begin{array}{l}\text { Total } \\
\text { oxygen } \\
\text { uptake }\end{array}$ & $\begin{array}{l}\text { Growth on } \\
\text { substrate } \\
\text { as sole } \\
\text { carbon }+ \\
\text { energy } \\
\text { source }\end{array}$ & $\begin{array}{l}\text { Total } \\
\text { oxygen } \\
\text { uptake }\end{array}$ & $\begin{array}{l}\text { Growth on } \\
\text { substrate } \\
\text { as sole } \\
\text { carbon }+ \\
\text { energy } \\
\text { source }\end{array}$ & $\begin{array}{l}\text { Total } \\
\text { oxygen } \\
\text { uptake }\end{array}$ & $\begin{array}{c}\text { Growth on } \\
\text { substrate } \\
\text { as sole } \\
\text { carbon+ } \\
\text { energy } \\
\text { source }\end{array}$ \\
\hline phenol & $\mathbf{0}$ & . & $\mathbf{0}$ & . & $\mathbf{0}$ & . \\
\hline pyrocatechol & $\mathbf{0}$ & - & $2 \cdot 16$ & + & $3 \cdot 14$ & + \\
\hline protocatechuic acid & $2 \cdot 73$ & + & $2 \cdot 22$ & + & $2 \cdot 40$ & + \\
\hline homogentisic acid & $\mathbf{3 \cdot 1 5}$ & . & $2 \cdot 39$ & . & $3 \cdot 21$ & . \\
\hline gentisic acid & $>\mathbf{2 \cdot 3 6}$ & . & $\mathbf{0}$ & . & $>1.43$ & . \\
\hline benzoic acid & $>0.68^{*}$ & . & $4 \cdot 90^{*}$ & . & $>4.50^{*}$ & . \\
\hline $\begin{array}{l}\text { o-hydroxybenzoic } \\
\text { acid }\end{array}$ & $>1.52^{*}$ & . & $>1.97^{*}$ & - & $>1.60 *$ & . \\
\hline $\begin{array}{l}m \text {-hydroxybenzoic } \\
\text { acid }\end{array}$ & $4 \cdot 39 *$ & + & 0 & - & $4 \cdot 30^{*}$ & + \\
\hline $\begin{array}{l}p \text {-hydroxybenzoic } \\
\text { acid }\end{array}$ & $\mathbf{0}$ & - & $3 \cdot 29^{*}$ & + & $3 \cdot 85^{*}$ & + \\
\hline cinnamic acid & $\mathbf{0}$ & - & . & - & $\mathbf{0}$ & - \\
\hline $\begin{array}{l}\text { o-hydroxycinnamic } \\
\text { acid }\end{array}$ & 0 & . & $\mathbf{0}$ & & $0 \cdot 86$ & - \\
\hline $\begin{array}{l}m \text {-hydroxycinnamic } \\
\text { acid }\end{array}$ & $>2 \cdot 44$ & + & $\mathbf{0}$ & - & $>4 \cdot 10$ & + \\
\hline $\begin{array}{l}p \text {-hydroxycinnamic } \\
\text { acid }\end{array}$ & o & - & $>1.21^{*}$ & + & 0.88 & - \\
\hline
\end{tabular}

A comparison of the oxygen uptake with meta- and para-hydroxybenzoic acids and hydroxycinnamic acids, respectively, as substrates (Table 2), reveals a configurative correlation. The meta-hydroxy acids only were oxidized by strain Ks 1741, and utilized as sole carbon + energy sources, whereas strain Ms 144412 was capable of oxidizing and utilizing the para-hydroxy acids but not the meta-hydroxy acids. Strain 0811 oxidized every one of the four acids, though $p$-hydroxycinnamic acid to a restricted extent, corresponding to $\mathbf{0 . 8 8}$ mole oxygen $/$ mole substrate. This oxygen uptake with $p$-hydroxycinnamic acid was obviously not connected with ring opening and did not provide energy enough to support growth (see Table 2). 
The reaction $m$ - or $p$-hydroxybenzoic acid $\rightarrow$ protocatechuic acid (Fig. 1) corresponds to an oxygen uptake of 1 atom oxygen/mole hydroxybenzoic acid. Accordingly the difference in oxygen uptake between hydroxybenzoic acid and protocatechuic acid should be 0.5 mole oxygen/mole substrate, provided that the oxidation of the hydroxybenzoic acids proceeds via protocatechuic acid, as has been demonstrated to be the case for soil fungi (Henderson, 1960, 1961) and for soil bacteria (Evans, 1947; Sleeper \& Stanier, 1950; Yano \& Arima, 1958). The oxygen uptake observed in repeated experiments with washed organisms of the present lignanolytic agrobacteria, as indicated in Table 3, presupposes greater differences. Instead of the theoretical difference, 0.5 mole oxygen/mole substrate, between oxygen uptake with protocatechuic acid and the hydroxybenzoic acids, respectively, 1.4 mole oxygen/mole substrate was found to be the actual difference between oxygen taken up with $m$-hydroxybenzoic acid and with protocatechuic acid as

Table 3. Total oxygen uptake (mole oxygen/mole substrate) observed in repeated experiments with washed organisms grown on glucose + yeast extract + nitrate + mineral salts, using p-hydroxybenzoic acid, m-hydroxybenzoic acid, and protocatechuic acid as substrate, and differences between obtained means for protocatechuic acid oxygen uptake and hydroxybenzoic acid oxygen uptake

\begin{tabular}{|c|c|c|c|c|c|c|}
\hline \multirow{2}{*}{ Substrate } & \multicolumn{6}{|c|}{ Organism } \\
\hline & \multicolumn{2}{|c|}{ Ks 1741} & \multicolumn{2}{|c|}{ Ms 144412} & \multicolumn{2}{|c|}{ O 811} \\
\hline $\begin{array}{l}p \text {-hydroxybenzoic } \\
\text { acid }\end{array}$ & & - & & $\begin{array}{l}\mathbf{3} \cdot 28 \\
\mathbf{3} \cdot 29 \\
\mathbf{3} \cdot 90\end{array}$ & & $\begin{array}{l}3 \cdot 57 \\
3 \cdot 96 \\
3 \cdot 74\end{array}$ \\
\hline & & & Mean & $\mathbf{3} \cdot 69$ & Mean & $3 \cdot 76$ \\
\hline $\begin{array}{l}m \text {-hydroxybenzoic } \\
\text { acid }\end{array}$ & & $\begin{array}{l}4 \cdot 39 \\
4 \cdot 02 \\
3 \cdot 93\end{array}$ & & - & & $\begin{array}{l}4 \cdot 05 \\
4 \cdot 24 \\
4 \cdot 46\end{array}$ \\
\hline & Mean & $4 \cdot 11$ & & & Mean & $4 \cdot 25$ \\
\hline protocatechuic acid & & $\begin{array}{l}2 \cdot 73 \\
2 \cdot 43 \\
2 \cdot 92\end{array}$ & & $\begin{array}{l}2 \cdot 22 \\
2 \cdot 32 \\
2 \cdot 41 \\
2 \cdot 74\end{array}$ & & $\begin{array}{l}\mathbf{2} \cdot 30 \\
\mathbf{3} \cdot 32 \\
2 \cdot 92\end{array}$ \\
\hline & Mean & $\mathbf{2 \cdot 6 9}$ & Mean & $2 \cdot 42$ & Mean & $\mathbf{2 \cdot 8 5}$ \\
\hline $\begin{array}{l}\text { Difference between } \\
m \text {-hydroxybenzoic } \\
\text { acid and proto- } \\
\text { catechic acid oxygen } \\
\text { uptakes }\end{array}$ & & $1 \cdot 42$ & & 一 & & $1 \cdot 40$ \\
\hline $\begin{array}{l}\text { Difference between } \\
p \text {-hydroxybenzoic } \\
\text { acid and proto- } \\
\text { catechuic acid oxygen } \\
\text { uptakes }\end{array}$ & & - & & $1 \cdot 27$ & & 0.91 \\
\hline
\end{tabular}

substrates. The corresponding figure for difference between $p$-hydroxybenzoic acid oxidation and protocatechuic acid oxidation was 0.9 or 1.3 mole oxygen/mole substrate. It is believed that the differences actually found give reason to assume that the metabolism of the hydroxybenzoic acids can be explained only partially by the intermediate formation of protocatechuic acid. Furthermore, the oxygen uptake 
with $m$-hydroxybenzoic acid was, on repeated occasions, found to be greater than the amount of oxygen consumed in the presence of $p$-hydroxybenzoic acid (see Tables 2, 3), which might indicate that the substrates were metabolized along different paths.

The transformation $m$-hydroxybenzoic acid $\rightarrow$ gentisic acid before ring cleavage (Fig. 1) occurs in pseudomonads (Walker \& Evans, 1952; Yano \& Arima, 1958). As mentioned above, the agrobacterial strains $\mathrm{Ks} 1741$ and $\mathrm{O} 811$, which are capable of oxidizing $m$-hydroxybenzoic acid, oxidized gentisic acid at a comparatively slow rate (see Fig. 3). The rate of gentisic acid oxidation should be limiting for

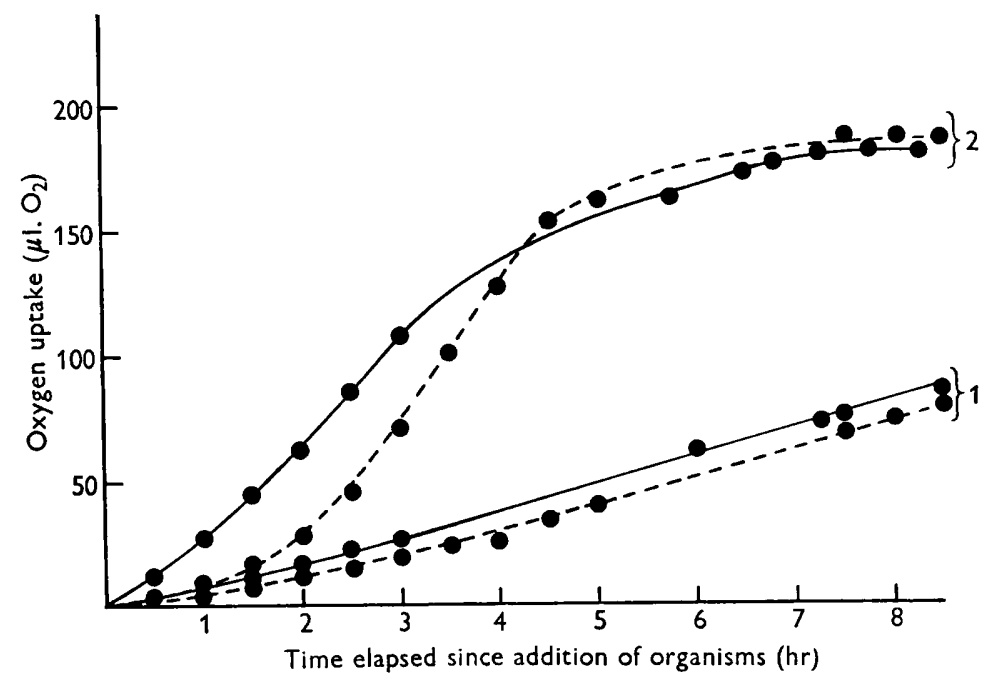

Fig. 4. Oxygen uptake by organisms of strain $O 811$ (not adapted to $\alpha$-conidendrin during growth) with gentisic acid and $m$-hydroxybenzoic acid. Effect of adaption to $m$-hydroxybenzoic acid. Number of viable organisms: broken curves, $3.5 \times 10^{10}$; whole curves, 1.6 $\times 10^{10}$. Amount of substrate: $2 \mu$ mole. Endogenous value subtracted. 1 , Gentisic acid; 2, $m$-hydroxybenzoic acid. Broken curves $=$ untreated organisms, whole curves $=$ organisms adapted to $m$-hydroxybenzoic acids prior to measurement through shaking with $0.001 \mathrm{~m} m$-hydroxybenzoic acid $\mathrm{pH} 5.5$ for $90 \mathrm{~min}$. at $28^{\circ}$.

the $m$-hydroxybenzoic acid oxidation, if this latter proceeds via gentisic acid. Organisms adapted to $m$-hydroxybenzoic acid through exposure to this substrate prior to measurement of oxygen uptake showed the same slow oxygen uptake with gentisic acid though the lag of $m$-hydroxybenzoic acid oxidation had been suppressed (Fig. 4). The results obtained provide grounds for the assumption that there was some unknown metabolic system which was working more rapidly than the gentisic acid oxidation, which accounted for the oxidative breakdown of $m$-hydroxybenzoic acid.

\section{DISCUSSION}

Classification of the Gram-negative bacteria indigenous to soil is rendered difficult by the lack of knowledge of dividing characteristics. There seems to be a need for a more detailed study of the Gram-negative rods of the soil as a group along the taxometric lines indicated by Gyllenberg (1963) and Hill \& Silvestri (1962), in order to establish a useful basis for the separation of this important part 
of the soil microflora. In the search for separating tests, the ability to utilize phenolic and lignin-related compounds might be of some value. Such reactions could be well suited to divide organisms which are possibly concerned with the breakdown of lignified plant residue in soil and characterized by inertness in ordinary biochemical tests.

The allocation of the present organisms by genus is a matter for discussion. According to the classification scheme of Holding (1960), followed in this work, the only difference between the criteria for placing an isolate in the genus Agrobacterium or Achromobacter is the ability to proliferate on inorganic nitrogen; when an organism has this ability it is placed in the genus Agrobacterium, and when it has not, in the genus Achromobacter. About one half of the Achromobacter species listed in the 7th edition of Bergey's Manual (1957) are described as having the capacity to use ammonium chloride as nitrogen source; the separation on grounds of nitrogen requirement thus puts together agrobacteria and achromobacteria. On tracing the lignanolytic bacteria examined here through the key to the Achromobacter species of the Bergey's Manual (1957), they will be considered as A. cycloclastes or A. pestifer. The former organism has been reported as decomposing phenol and naphthalene. Though none of the present bacteria is able to attack phenol (see Table 2), a relationship to this previously isolated, peritrichously-flagellated, non-pigmented, Gramnegative rod lies near at hand. The type of flagellation (few flagella), Gram reaction (granular staining with a tendency to variability), the small size of the organisms, and reactions typical of Agrobacterium radiobacter, listed in Table 1, have contributed to consideration of the present organisms as representatives of the genus Agrobacterium.

The oxidation of $p$ - and $m$-hydroxybenzoic acid by microbes is known to be initiated by the introduction of a second hydroxyl group, resulting in either gentisic acid or protocatechuic acid, which are further oxidized during the opening of the aromatic ring and the formation of energy-yielding metabolites as shown in Fig. 1. These reactions might be affected by the organisms under discussion, but the stoichiometric differences in oxygen uptake observed with washed organisms for $m$ - and $p$-hydroxybenzoic acids and protocatechuic acid, indicates that the $p$-hydroxybenzoic acid oxidation by strain $\mathrm{O} 811$ and Ms 144412, consuming roughly 7 oxygen atoms/mole substrate, cannot proceed only along the path via protocatechuic acid, which is oxidized to a degree corresponding to the uptake of 5 atoms oxygen/mole substrate. The probability that the oxidation proceeds via protocatechuic acid is still less if $m$-hydroxybenzoic acid oxidation by organisms Ks 1741 and $O 811$ is in question. This substrate is oxidized to a degree which corresponds to 8 or 9 atoms oxygen/mole $m$-hydroxybenzoic acid. Under the prevailing conditions, the oxidation of gentisic acid by the strains which oxidize $m$-hydroxybenzoic acid is too slow to allow of the evaluation of the total consumption of oxygen. Even if the stoichiometric amount of total oxygen consumed were in agreement with the hypothesis that $m$-hydroxybenzoic acid is oxidized via the formation of gentisic acid, the rate of gentisic acid oxidation, in connexion with the inability of $m$-hydroxybenzoic acid-adapted organisms to cause increased oxidation of gentisic acid, cannot satisfactorily support such a view. 
This work was part of a project supported by grant No. FG-Fi-108-60 from the U.S. Department of Agriculture, Washington, D.C., and follows number 1 in a series on microbial decomposition of lignins (Sundman, 1962).

\section{REFERENCES}

Bergey's Manual of Determinative Bacteriology (1957). 7th ed. Ed. by R. S. Breed, E. D. G. Murray \& N. R. Smith. Baltimore: Williams and Wilkins.

Brisbane, P. G. \& Rovira, A. D. (1961). A comparison of methods for classifying Rhizosphere bacteria. J. gen. Microbiol. 26, 379.

Cons, H. J. (1942). Validity of the genus Alcaligenes. J. Bact. 44, 359

ConN, H. J. (1948). The most abundant groups of bacteria in soil. Bact. Rev. 12, 257.

Dagley, S., Evans, W. C. \& Ribions, D. W. (1960). New pathways in the oxidative metabolism of aromatic compounds by micro-organisms. Nature, Lond. 188, 560.

Evans, W. C. (1947). Oxidation of phenol and benzoic acid by some soil bacteria. Biochem. J. 41, 373.

Fukuzumi, T. (1962). Enzymatic degradation of lignin. Part II. Oxidation of homogentisic acid and gentisic acid by the enzyme of the wood-rotting fungus Portia subacida. Agr. Biol. Chem., Tokyo, 26, 447.

Gyllenberg, H. (1963). A general method for deriving determination schemes for random collections of microbial isolates. Ann. Acad. Sci. fenn. Ser.A, 4. No. 69.

Henderson, M. E. K. (1960). The influence of trace elements on the metabolism of aromatic compounds by soil fungi. J. gen. Microbiol. 23, 307.

Henderson, M. E. K. (1961). The metabolism of aromatic compounds related to lignin by some hyphomycetes and yeast-like fungi of soil. J. gen. Microbiol. 26, 155.

Higuchi, T., Kavamura, I. \& Hayashi, I. (1956). Biochemical study of wood-rotting fungi. V. The enzymatic oxidation of lignins. J. Japan. Wood Res. Soc. 2, 31.

Hill, L. R. \& Silvestri, L. G. (1962). Quantitative methods in the systematics of Actinomycetales. III. The taxonomic significance of physiological-biochemical characters and the construction of a diagnostic key. Giorn. Microbiol. 10, 1.

HoDGkiss, W. (1960). The interpretation of flagella stains. J. appl. Bact. $23,398$.

Hofer, A. W. (1941). A characterisation of Bacterium radiobacter (Beijerinck and van Delden) Löhnis. J. Bact. 41, 193.

Holding, A. J. (1960). The properties and classification of the predominant Gramnegative bacteria occurring in soil. J. appl. Bact. 23, 515.

Hugh, R. \& LeIfson, E. (1953). The taxonomic significance of fermentative versus oxidative metabolism of carbohydrates by various Gram-negative bacteria. J. Bact. 66, 24.

Ishikawa, H., Schubert, W. J. \& Nord, F. F. (1963a). Investigations on lignins and lignification. XXVII. The enzymic degradation of soft wood lignin by white-rot fungi. Arch. Biochem. Biophys. 100, 131.

Ischikawa, H., Schubert, W. J. \& Nord, F. F. (1963b). Investigations on lignins and lignification. XXX. Enzymic degradation of guaiacylglycerol and related compounds by white-rot fungi. Biochem. Z. 338, 153.

Konetzka, W. A., Pelczar, M. J. \& Gottlieb, S. (1952). The biological degradation of lignin. III. Bacterial degradation of $\alpha$-conidendrin. J. Bact. 63, 771.

Konetzka, W. A., Woodings, E. T. \& STove, J. (1957). Microbial dissimilation of methoxylated aromatic compounds. Bact. Proc. p. 135.

LACK, L. (1959). The enzymic oxidation of gentisic acid. Biochim. biophys. Acta, 34, 117.

Leifson, E. (1960). Atlas of Bacterial Flagellation. New York: Academic Press.

Rhodes, M. E. (1958). The cytology of Pseudomonas spp. as revealed by a silver-plating staining method. J. gen. Microbiol. 18, 639.

Riker, A. J., Banfield, W. M., Wright, W. H., Keitt, G. W. \& Sagen, H. E. (1930). Studies on infectious hairy root of nursery apple trees. J. Agric. Res. 41, 507.

RogofF, M. H. (1961). Oxidation of aromatic compounds by bacteria. In Advances in Applied Microbiology. Ed. by W. W. Umbreit, vol. 3. New York: Academic Press. 
SAGEN, H. E., Riker, A. J. \& Baldwin, I. L. (1934). Studies on certain physiological characters of Phytomonas tumefaciens, Phytomonas rhizogenes, and Bacillus radiobacter. Part 1. J. Bact. 28, 571.

Sleeper, B. P. \& Stanier, R. Y. (1950). The bacterial oxidation of aromatic compounds. I. Adaptive patterns with respect to polyphenolic compounds. J. Bact. 59, 117.

Stanier, R. Y. (1947). Simultaneous adaption. A new technique for the study of metabolic pathways. J. Bact. 54, 339.

Stanier, R. Y. \& Ingraham, J. L. (1954). Protocatechuic acid oxidase. J. biol. Chem. $210,799$.

Sugryama, S., Yano, K., Tanaha, H., Komagata, K. \& Arima, K. (1958). Metabolism of aromatic compounds by bacteria. I. Gentisic acid oxidase and protocatechuic acid oxidase of Pseudomonas ovalis S-5. J. gen. appl. Microbiol., Tokyo, 4, 223.

Sundman, V. (1962). Microbial decomposition of lignins. I. Identification of isovanillic acid as a breakdown product in bacterial degradation of $\alpha$-conidendrin. Medd. finska Kemistsamf. 71, 26.

Sundman, V. (1964). The ability of $\alpha$-conidendrin-decomposing Agrobacterium strains to utilize other lignans, and lignin-related compounds (in preparation).

Sörensen, H. (1962). Decomposition of lignin by soil bacteria and complex formation between autoxidised lignin and organic nitrogen compounds. J. gen. Microbiol. 27, 21.

Tabak, H. H., Chambers, C. W. \& Kabler, P. W. (1959). Bacterial utilization of lignans. J. Bact. 78, 469.

Thonnley, M. J. (1960). The differentiation of Pseudomonas from other Gram-negative bacteria on the basis of arginine metabolism. J. appl. Bact. 23, 37 .

Umbreit, W. W., Burris, R. H. \& Stauffer, J. F. (1957). Manometric Techniques. Minneapolis: Burgess Publishing Co.

Walker, N. \& Evans, W. C. (1952). Pathways in the metabolism of monohydroxybenzoic acids by soil bacteria. Biochem. $J$. 52, xxiii.

Yano, K. \& Arima, K. (1958). Metabolism of aromatic compounds by bacteria. II. $m$-Hydroxybenzoic acid hydroxylase $A$ and B, 5-dehydroshikimic acid, a precursor of protocatechuic acid, a new pathway from salicylic acid to gentisic acid. J. gen. appl. Microbiol., Tokyo, 4, 241.

ZoBell, C. E. \& Feltham, C. B. (1934). A comparison of lead, bismuth, and iron as detectors of hydrogen sulphide produced by bacteria. J. Bact. 28, 169 . 